\title{
Character Education in Madrasah Mu'allimin Muhammadiyah Yogyakarta
}

\author{
E W Junaidi ${ }^{1}$, S Rochmat ${ }^{2}$ \\ Post-graduate, Universitas Negeri Yogyakarta, Indonesia \\ 1Ekowjwj@gmail.com,2rochmat@yahoo.com
}

\begin{abstract}
Character education becomes the main focus of the Indonesian pedagogy sector. Along with the national goal of education, Madrasah Mu'alliminMuhammadiyah Yogyakarta existed as an institution that focuses on building the character of its students. This research aims to describe the ongoing pedagogy practices in Madrasah Mu'allimin. This research is using a qualitative approach.The result of this study shows that character-building becomes one of the primary objectives, along with education and religion. Each form of activity in school or dormitories intended to enhance the character development of the students. The designated schedule carefully arranged by the teachers, straight down for each day. Hopefully, this arrangement would be accustomed to the students when they are graduating from school. The character development from Madrasah Mu'allimin could prepare the students to become a valuable human being for the society, nation, and country.
\end{abstract}

Keywords: Education, Character, Muhammadiyah.

\section{Introduction}

Education is a conscious act towardsthe development of the people and society according tocertain ideas in purpose to humanize a human being[1]. While according to Suryadi [2], education is a conscious act carried out by family, society, and government in forms of mentoring activities, training in and outside of school to prepare the students in fulfilling their role in various places. The ultimate objective of education is to combine both personal development and dedicated roles accordingly.

Character development seems to be one of the educational goals. This goal contained in the first article of the 2003 SISDIKNAS act, which explains that the purpose of education is to improve the intelligence, character, and moral potencies of the students.[3] stated that character education is a value system that provides students with components of intelligence, awareness, and visible action to carry out those values so that they become a wholesome human being. Thus, character education can be concluded as a character developing process that creates a generation that possesses dignity and noble characters.

Looking back on the goals of national education which also including the character development, there were Indonesian figures who already promoting character education. One of the people who do that is K.H. Ahmad Dahlan, the founder of Muhammadiyah. He established the Muhammadiyah to implement his ideas, including his concepts about education. He barely wrote books about his ideas on pedagogy matters. His ideas were only 
written in books years after his death, by people who gather information from his closest ones. Through the literature, we can see that his idea about education goes from the fundamental of Islamic reformation in education, which contains the goal of education, the implementation technique, and the education process itself[4].

His concept of education is basically about the perfection of morals which comes from the understanding of good and bad, right or wrong, happiness and sorrow, and act according to those things [5]. This concept of education remarkably associated with his Hajj experience and his study in Mecca. Some people also inspire him about the concept of education, such as Jmaludin al-Afgani, Muhammad Abduh, dan Rasyid Ridha. They gave him new insights which he then tries to implement on the education of the people.

In 1911, years before K.H. Ahmad Dahlan established Muhammadiyah, he made an educational institution of religion and common sciences to his students. His first school started with just eight students and using his living room as the class where he also becomes the teacher. Until December $1^{\text {st }}, 1911$, he established an institution called Madrasah IbtidaiyahDiniyahIslamiyah. On its first launch, there were 29 students in this school. The amount increased to 62 after six months [6].

K.H. Ahmad Dahlan created the Muhammadiyah organization and applying for legal permission to the Dutch Government on November 18, 1912[7]. The Dutch Government approved the submission two years after in 1914, restricting Muhammadiyah to only operating around Yogyakarta[8]. Using another name of the institution then becomes a loophole strategy against this restriction. Like the Nurul Islam in Pekalongan, Al-Munir in Makassar, and Ahmadiyah in Garut[9].

After Muhammadiyah getting a legalization from the Dutch Government in 1914, K.H. Ahmad Dahlan introduced Madrasah QismulArqa in 1918 in KampungKauman, Yogyakarta where he himself become the manager. Along its period, Madrasah QismulArqachanging its name several times, like KweekschoolMuhammadijah, HogereMuhammadijah School, then finally changed into MualliminMuhammadijah Yogyakarta. The later name has been used since 1941 until now as the result of the Muhammadiyah $23^{\text {rd }}$ congress on July 19-25, 1934 in Yogyakarta[10].

Madrasah Muallimin Muhammadiyah Yogyakarta is an institution which focuses on the development of its member, directly supervised by the PP Muhammadiyah to create imams, leaders, and teachers. Madrasah Muallimin provides an integrative regular and theology class as a formal educational institution. According to its vision, mission, and goals, Madrasah MualliminMuhammadiyah Yogyakarta focuses on becoming an excellent education institution and able to produce prospective imams, leaders, and teachers that would convey the missions of Muhammadiyah[11].

Mu'allimin school becomes the school that develops the prospective people for the sake of Muhammadiyah organization. The school has gone through various periods since the establishment of Indonesia. Mu'allimin becomes a school that able to withstand changes by the adaptive management of the institution so that it can keep carrying the goals of the school until now. According to the previous descriptions, the writer aims to study the "character education in Madrasah Mu'alliminMuhammadiyah Yogyakarta”. 


\section{Research Methods}

This research is using a qualitative approach. Qualitative research often called the naturalistic research method because of the natural environment that it observes. Qualitative research observes social events as a whole, complex, dynamic, meaningful, and reciprocal relation between each event. The research will observe the objects as is, no manipulation by the researcher, and his presence serves no effect on the dynamic condition of the objects themselves. There is only one instrument in qualitative research, which is the researcher himselfas a human instrument [12]. This research was conducted in february to march 2020.

\section{Results and Discussion}

Character education tends to be more acceptable in Indonesia, particularly by Muslim philosophers. Not because of the concept or theories, but because character education has implicitly included in Islamic teachings. Islamic education fundamentally is a method to make the students become a noble human being with dignity and proper morals, thus they would be loved by Allah. Baidarus [13]stated that character education exists since the birth of Islamic education because character education is the core of Islamic education itself.

Character education would be a success if all the nation-building component are combined with the character building of the citizens. Muhammadiyah is one of the largest private institutions in Indonesia. Along with the vision of its founder, K.H. Ahmad Dahlan, Muhammadiyah carries out its education process to develop the character according to the values of the Quran and Sunnah. Baidarus [13] also stated that the effort of Muhammadiyah schools to build character is a form of noble act, especially when discussing the future, the schools under its management, which they responsible for not only students who are excelling in academic and science capabilities, but also in character, identity, and personality. According to Zamroni[14], Madrasah Mu'allimin Muhammadiyah Yogyakarta could be one of the schools that capable of carrying out the deed.

In the implementation, the character development in Madrasah Madrasah Mu'allimin Muhammadiyah Yogyakarta combines the cultural and religious aspects with a moral reasoning system. Muhammadiyah has achieved this visionary method through its education system, which combines the aspects of culture, religion, and education. Long before the current government promoting character education based on cultural and national identity.

The combination of religion, culture, and scientific aspects in Muhammadiyah could lift its image on character and contributes to Indonesia by providing the figures with strong nationalism and responsibility to the nation's duties. The members of Muhammadiyah possess great credibility in the nation's existence in this era.

Muhammadiyah published a guide book about its concept as a guide to developing the character of its students. The congress' result becomes the fundamental content of the guide, which contains the moral reasoning system. The teachers would be referring to this book when they transferring the moral knowledge to the students. Madrasah Mu'allimin Muhammadiyah Yogyakarta improves the capabilities of its students so that they would be highly beneficial to society. Along with the goals of Muhammadiyah which is to provide Muslim beings with decent morals, smart, confident, and useful to the society, as well as promoting a good example of Islam religion to achieve the true Islamic society. The goals of Muhammadiyah's 
education can be divided into two kinds, the national education and Muhammadiyah education.

a) National education, which is to provide smart graduates and democratic citizen that takes responsibility for the prosperity of the society and the nation.

b) Muhammadiyah education, which is to make Muslim being, excelling in morals, smart, confident, and useful to the society.

Madrasah Mu'allimin Muhammadiyah Yogyakarta enacting the character education to their students through their daily lives, whether in school or the dormitory. Their daily activities also containing implemented character values, with a goal that one day they would implement those values in their lives after they graduating from the school.

Muhammadiyah's education divides moral values into two forms of moral reasoning systems, the first one is in the context of struggling values, role models, and organization. The second one is religious and cultural values. The first values designated to be transferred to the first and second-year students, where they will learn about the struggling of the organization and its founding fathers in enacting the purification of Islamic teachings [14].

Moral reasoning of religion and culture in third-year classesbecomes a guide to the reality of life. These values include several Islamic values that believed to true and become a backrest for students in carrying out their daily lives[14]. The Madrasah Mu'allimin Muhammadiyah Yogyakarta is a school model as a boarding school. In the context of boarding school model education, the existence of a teacher or coach as an example is crucial because the behavior of authority figures becomes an example/model that is easily imitated by students. According to Bandura[15] regarding modeling that is associated with learning theory, four processes passed in the human psychological process, namely attention, retention, reproduction, and motivation. The teacher is an individual who is an example in modeling in the school environment.

Learners will make observations by paying attention, maintaining memories of the figure and behavior, bringing up action following the representation of the role model to be imitated, and encouraging to do the role model exemplified in the process of mental formation. The Madrasah Mu'allimin Muhammadiyah Yogyakarta situation as a boarding school shows that a dormitory is a family unit. In the family dormitory, there is active communication between the figures of the teacher/tutor boarding/musrifah. The growth of trust makes students feel comfortable in conveying their thinkings and feelings, and the growth of perceptions of the values socialized by the teacher/tutor of the dormitory/ musrifah [16].

The students are scout by religious character, independence, and attitude of responsibility in the environment dormitory. They live in a dormitory. They must be able to arrange a time to study, organize, and perform worship services. These things are a form of responsibility towards yourself. They must be able to independence because they live with friends and away from parents independently. Religious character is prominent in character education in the Madrasah Mu'allimin Muhamadiyah Yogyakarta.

Religious character is one of the character education values. Religious values relate to the thoughts, words, and actions of a person who are pursued based on the divinity values and the teachings religious. According to Sapitri [17], religious character values become that educations are very important because individual belief in the truth of value derived from they hold can be strong motivation in building character. Teachers need to pay attention to a few points to implement religious character values [17] in the success of character education by integrating subjects, developing themselves through daily activities, and exemplary.

Religious character is the relationship between science that needs to realization with the aspect of religion and its relationship with God and fellow human beings. Science emphasis the existence of God that has a lot of knowledge and has entrusted to humans. These things 
become one of the reasons why religious values are explained and stimulated first so that students can easy to learn.

The character education model in the Madrasah Mu'allimin Muhammadiyah Yogyakarta emphasizes Islamic (religious) values. Al-Quran and As-Sunnah are instructions in carrying out an action based on Islamic values. Ijtihad is a way to determine things that are not yet present or unclear in Al-Qur'an and Sunnah. According to Kuswono [18] that the curriculum system in Madrasah Mu'allimin Muhammadiyah Yogyakarta set to incorporate Quranic values with guidance from a curriculum integrated with Islamic teachings and remains balanced with other knowledge.

The purpose of Madrasah Mu'allimin from the principles of the tafaqquh fiddin curriculum is a religious value, containing religious subjects with a percentage of $80 \%$ religion and $20 \%$ general. The curriculum refers to the yellow book such as fiqh, ushul fiqh, interpretation, hadith, the science of hadith, the interpretation of science, balagah, mantiq, and so on. Students learn materials as provisions to become qualified scholars [19].

Madrasah Mu'allimin Muhammadiyah Yogyakarta also instills character education appreciating and respecting others. Students always accompanied by prayers in the learning processes beginning and ending activities. Students also accustomed to exchanging Smiles, Greetings, Say Hello, Polite, and Courteous, when classmates meet with classmates or other students when they meet teachers greet each other.

As a cadre school, cadre education in Madrasah Mu'allimin Muhammadiyah Yogyakarta has a vision of giving birth to cadres of ulama, leaders, and educators as mission bearers of the Muhammadiyah movement. It missions see that religious values and leadership include in the Madrasah missions which read as follows: "Organizing and Developing Islamic education to build competencies and excellence students in the fields of basic Islamic sciences, science, technology, arts, and culture, organize and develop leadership education to build the competencies and excellence of students in the field of organization and struggle of Muhammadiyah" [20].

Madrasah Mua'llimin Yogyakarta has various organizations, one of the organizations is the IPM (Muhammadiyah Student Association). Through the Muhammadiyah Student Association, the students instill curiosity to be critical of the surrounding environments. Students get character education with the curiosity value so that become critical of the surrounding environment situation. Learners also become concerned about the surrounding environment. They become caring because they care about small things so that their sensitivity to everything big problems wherever they are.

The IPM organization is responsible for the Baitul Arqam 1 and 2 activities for classes VII and VIII. The materials include time management, leadership, and Muhammadiyah material for the Madrasah level on the history and founder of Muhammadiyah. Another form of training is public speaking. Public speaking arranged to be able to speak in public with a culture, at least in one generation. Leadership values are the main thing besides the religious value derived from the mission of Mu'allimin.

Extracurricular Hizbul Wathan (HW) is the same activity as scouts. HW shaping the nature of leadership, discipline, love for the homeland, and oriented to the principle of "Educative, Reactive, and Religion". This has the purpose as a foundation and guideline to fight for the nation and the motherland. HW has a history with a scouting movement founded by K.H Ahmad Dahlan in Yogyakarta in 1918. HW was originally named Muhammadiyah padventer and scouting pioneers before Scouting founded in Indonesia.

The difference between the HW advance (before scouting) and the new HW (after approval) is the difference in organizational status. HW used to be an assembly, while HW is 
now an autonomous organization in the Muhammadiyah environment by applying an education system that remains the same, but the training methods and techniques adapt to the development of today's student development. Uniforms and attributes use to accommodate by adjusting the tastes of young people and remain in religious norms.

The school carries out HW activities by recruiting supervisors to help it. There are eight subject matter skills lessons include [21]: Tali Temali (making pioneering consisting of knots and woven knots); sign language (watchword) (as a medium of communication and coordination consisting of semaphores and codes including morse); marching lines (as a disciplined investment consisting of cues with words and whistles); mapping (to report on trips, tours, and adventures); estimating (as a practical technical skill which includes assessing height, width, depth, weight, weather, and river currents); first aid (to provide first aid or temporary); compass (to find out the direction of the road); health (including physical health including body health and nutritious food).

HW activities added to the eight materials have additional skills that are taught religious activities as a medium for planting Islamic material and Muhammadiyahan. Meanwhile, the teaching method consists of a team system (congregation) that instills the value of unity, cooperation, taking responsibility as a team, or in athfal units called "kuntum"[22].

Madrasah Mu'allimin Muhammadiyah Yogyakarta has a method of character education through the example of figures who can inspire students and become role models. Exemplary is realized by connecting into learning material so that students can take inspiring values. One of the role models is the figure of K.H. Ahmad Dahlan. He highlighted the spirit to be diligent in charity and the vigor to work within the community. Social action needs real action in doing not only for organizations or communities but also for individuals.

The nature of leadership K.H. Ahmad Dahlan became a significant point as an example. He can coordinate Muhammadiyah members in organizing well. He had a character that can accept and respect by the community so he had a track record in various organizations and can establish Muhammadiyah organizations.

K.H. Ahmad Dahlan always sensitive to the environment and always a good personality who becomes a respected figure. He throughs the Muhammadiyah organization could spearhead charitable social and educational endeavors that are indispensable for the nation's revival and progress. The teachings provide Islamic teachings by upholding the amar makruf nahi munkar. He also invited to do good to all humans.

Not only religious and leadership values, but also other character values found in students. Responsibility, discipline, self-confidence, and moral values are values taught. These values are visible from the extracurricular activities of Hizbul Wathan, Mubgaligh Hijrah, and Tapak Suci. Examples of the application of character education to students from the results of interviews conducted with one of the students said:

"The BGM (Bimbingan Generasi Mubaligh) activities surround the city of Jogja with available posts giving us lessons to preach in the community, such as in the northern square for speeches. The goal is to train our minds."

The exposure of these students is one of the things instilled in the Madrasah Mu'allimin Muhammadiyah Yogyakarta by practicing mentality, self-confidence values, and so on. Responsibility for the tasks given is also one of the values inserted in the BGM activities. 


\section{Conclusion}

The implementation of character education in Madrasah Mu'allimin Muhammadiyah Yogyakarta combines aspects of culture and religion with a system of moral reasoning. In moral reasoning in the fields of religion and culture, Muhammadiyah's visionary has focused it through Kemuhammadiyahan and moral education. The development of character education in Muhammadiyah that combines aspects of culture, religion, and education has taken place long before the government has a character education program based on culture, national character, and education. Madrasah Mu'allimin Muhammadiyah Yogyakarta's fostering the ability of students or students with character education with the aim that students are beneficial to the community.

The students in the Madrasah Mu'allimin Muhammadiyah Yogyakarta teach in their daily lives both at school and when in the dormitory for scouting character. The dormitory environment of Santri instilled an attitude and a personality to be independent and responsible. They live to be able to arrange a time to study, organize, and worship in the dormitory. These things are a form of responsibility towards yourself. They also must independence because they live with friends far from parents who need it.

Character education at Madrasah Mua'llimin gets used to smiling, greeting, say hello, polite, and courteous. Students always pray before and after learning. Extracurricular and community in Madrasah Mu'allimin give influence in character education. Mu'allimin instills in students the character of curiosity, discipline, leadership, love of the motherland. Madrasah Mu'allimin also provides character education through figures that can inspire students and become role models. Exemplary is realized by connecting into learning material so that students can take inspiring values.

\section{References}

[1] D. Siswoyo, Ilmu Pendidikan. Yogyakarta: UNY Press, 2013.

[2] R. A. Suryadi, Ilmu Pendidikan Islam. Yogyakarta: deepublish, 2018.

[3] S. Narwati, Pendidikan Karakter. Yogyakarta: Familia, 2011.

[4] W. Lenggono, "Telaah Pemikiran K.H. Ahmad Dahlan Tentang Pembaruan Pendidikan Islam di Indonesia," UIN Sunan Kalijaga, vol. 19, p. 56, 2018.

[5] D. Kumalasari, Agama dan Budaya Sebagai Basis Pendidikan Karakter di Sekolah. Yogyakarta: suluh media, 2018

[6] N. A. Ch, Matahari Pembaruan - Rekam Jejak KH Ahmad Dahlan. Yogyakarta: galangpress, 2010.

[7] A. Shihab, Membendung Arus: Repons Gerakan Muhammadiyah Terhadap Penetrasi Misi Kristen di Indonesia. bandung: mizan, 1998.

[8] Khalimi, Ormas-Ormas Islam: Sejarah, Akar, Teologi dan Politik. jakarta: gaung persada press, 2010.

[9] M. Febriansyah et al., Muhammadiyah 100 Tahun Menyinari Negeri. Yogyakarta: majelis pustaka dan informasi PP Muhammdiyah, 2013.

[10] "Sejarah Madrasah Mu'allimin Muhammadiyah Yogyakarta," 2020. http://xn--mualliminhb0e.sch.id/sejarah/ (accessed Mar. 08, 2020).

[11] T. Pransiska and A. Aulia, "Pendekatan Sistem Pembelajaran Bahasa Arab di Madrasah Mu'allimin Muhammdiyah Yogyakarta," J. Penelit. Pendidik. Agama dan Keagamaan, vol. 16, p. 154, 2018.

[12] Sugiyono, Metode Penelitian Kuantitatif Kualitatif dan R\&D. bandung: alfabeta, 2009. 
[13] Baidrus, "Muhammadiyah dan Pendidikan Karakter di Indonesia," islamika, vol. 1, pp. 25-44, 2018.

[14] L. R. Zamroni, "Pendidikan Karakter peserta Didik di SMP Muhammadiyah 1 Yogyakarta dan SMP Muhammadiyah Kota Tidore," Harmon. Sos., vol. 1, p. 16, 2014.

[15] A. Bandura, Self-Efficacy The Exercise of Control. New York: W. H. Freeman and Company, 1997.

[16] D. Sulisworo, "Pembentukan Karakter Berbasis Nilai Melalui Sekolah Berasrama Pada Sekolah Islam di Indonesia," Pros. reforming Pedagog., p. 137, 2016.

[17] N. Sapitri and N. Hidayah, "Implementasi Pendidikan Karakter Religius Melalui Ekstrakurikuler Hizbul Wathan di SD Muhammadiyah Karangkajen II," Fundadikdas, vol. 1, p. 336, 2019.

[18] Kuswono, "Character Education Muhammadiyah Pattern (Case Study SMA Muhammadiyah 1 and MA Muallimin Yogyakarta)," Guid. J. Ilmu Pendidikan, Psikologi, Bimbing. dan Konseling, vol. 3, p. 46, 2013.

[19] A. Ma'arif, "Sitem Pendidikan Kader Madrasah Mu'allimin Muhammadiyah Yogyakarta dan Madrasah Mu'allimin Bahrul Ulum Jombang Jawa Timur,” UIN Sunan Kalijaga, 2019.

[20] "Visi dan Misi." https://muallimin.sch.id/visi-dan-misi/.

[21] A. B. S. Boyman, Ragam Latih Pramuka. bandung: nuansa muda, 2001.

[22] Gerakan Kepanduan HW, Bahan Pelatihan Kursus Jaya Melati I Kepanduan Hizbul Wathan. Yogyakarta: Pusat Pengadaan Perlengkapan HW Kwartir Pusat Hizbul Wathan, 2008. 